\title{
In vitro sensitivity of Monilinia laxa to fungicides approved in integrated and organic production systems
}

\author{
Holb, I.J., Fazekas, M. \& Abonyi, F. \\ University of Debrecen, 138 Böszörményi St., 4032 Debrecen, Hungary
}

\begin{abstract}
Summary: The aim of this study was to test the in vitro sensitivity of two isolates of Monilinia laxa to fungicides approved in integrated and organic production systems. In vitro efficacy of 7 fungicides (Champion 50 WP, Kocide 2000, Nordox 75 WG, Olajos rézkén, Kumulus S, Rézkén, Rézoxiklorid) and another 6 fungicides (Score 25 EC, Efuzin 500 SC, Systane, Folicur Solo, Zato Plusz, Rovral) approved in organic and integrated production systems, respectively, were tested against brown rot of sour cherry. The three isolates showed differences in sensitivity to fungicides. Fungicides (with active ingredients of copper and sulphur) applied in organic production showed relatively high percent growth capacity of M. laxa. Rézkén and Kocide 2000 showed the highest and Kumilus S the lowest efficacy against brown rot. Fungicides applied in integrated production showed relatively low percent growth capacity of M. laxa. Score 25 EC showed the lowest and Rovral and Folicur solso the highest efficacy against M. laxa.
\end{abstract}

Key words: brown rot, Monilinia laxa, organic, integrated, in vitro, fungicides

\section{Introduction}

Disease and pest management practices in integrated and organic production differ markedly from those in conventional production (Anon., 2000; Cross \& Dickler, 1994). Synthetic products are restricted in integrated and banned in organic apple production. In organic apple growing, only natural products such as compost, soluble rock powder, sulphur and copper compounds, fungicidal and botanical soaps, traps and biological methods are permitted against fungal diseases and pests according to IFOAM (International Federation of Organic Agriculture Movements) standards (Anon., 2000), while many synthetic pesticides can be used in integrated production.

Brown rot blossom blight, caused by Monilinia laxa (Aderhold \& Ruhland) Honey, is a devastating disease of stone fruit. The disease is endemic in Europe and causes epidemics in stone fruit orchards (Wormald, 1954; Byrde \& Willetts, 1977; Tamm et al., 1995; Holb \& Schnabel, 2005). In rainy springs, blossom blight causes severe crop losses in sour cherry orchards in Hungary (Holb, 2003, Soltész, 1997). Depending on weather conditions, blossom blight can be controlled with one to three applications of protectant or systemic fungicides during the bloom period in conventionally grown stone fruit orchards. Severe rain events before harvest can cause cracking of fruit and therefore sour cherry trees require one to two fungicide applications to avoid brown rot of matured fruit (Holb, 2004).

Variation in cultural characteristics of $M$. laxa isolates is known (Batra, 1991). Variation in growth rate, colony margin (lobbed, partly lobbed, and not lobbed), and culture colour (gray, buff, brownish, and several combination these colours) was reported among M. laxa isolates (Holb, 2003).

The aim of this study was first to test the in vitro sensitivity of two isolates of M. laxa to fungicides approved in integrated and organic production systems.

\section{Materials and methods}

Two isolates of M. laxa was used for this study which were collected from sour cherry orchards. One isolate was used from one separate year (2009 and 2010). Isolates were identified on the basis of morphological traits. Single-spore isolates were maintained on potato dextrose agar (PDA) in Petri dishes in the dark at 18 to $22{ }^{\circ} \mathrm{C}$. Short-term storage was at $4^{\circ} \mathrm{C}$ on PDA.

In vitro efficacy of 7 fungicides (Champion $50 \mathrm{WP}$, Kocide 2000, Nordox 75 WG, Olajos rézkén, Kumulus S, Rézkén, Rézoxiklorid) and another 6 fungicides (Score 25 EC, Efuzin 500 SC, Systane, Folicur Solo, Zato Plusz, Rovral) approved in organic and integrated production systems, respectively, were tested against apple scab. Fungicides were admended in PDA media. Two dosages were used: i) $1 \mathrm{x}$ dosage recommended by the manufacturer and ii) $0.5 \mathrm{x}$ dosage of the recommended dosage. Conidia of M. laxa were placed on Petri dishes admended with fungicides. Dishes were incubated for 24 hours at near saturation humidity at $18{ }^{\circ} \mathrm{C}$. Germination of conidia was evaluated after 24 hours incubation and percent growth capacity (GC) of the fungus was evaluated as $\mathrm{GC}=\mathrm{X} / \mathrm{Y} \mathrm{x}$ 100 , where ' $\mathrm{X}$ ' is percent germination of conidia in a 
fungicide plate, and ' $\mathrm{Y}$ ' is the percent germination of conidia in control plate.

\section{Results and discussion}

\section{Manufacturer dosages of fungicides}

Fungicides (with active ingredients of copper and sulphur) applied at $1 \mathrm{x}$ dosage recommended by the manufacturer in organic production showed relatively high percent growth capacity of M. laxa (16-53\%) (Figure 1a,b).
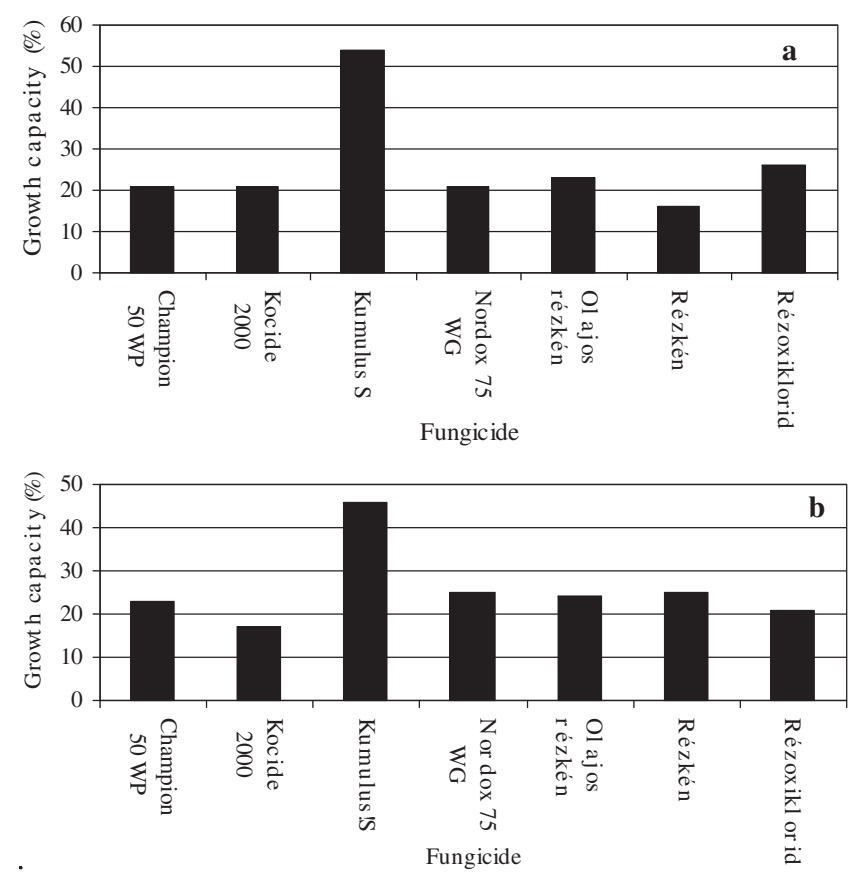

Figure 1. Percent growth capacity of two Monilinia laxa isolates (a and b) for 7 fungicides (organically approved) admended on PDA plates at $1 \mathrm{x}$ dosage recommended by the manufacturer.

The two isolates showed differences in sensitivity to fungicides. Especially sulphur had low in vitro effeciacy against brown rot. Rézkén and Kocide 2000 showed the highest and Kumilus S the lowest efficacy against M. laxa.

Fungicides applied at $1 \mathrm{x}$ dosage recommended by the manufacturer in integrated production showed relatively low percent growth capacity of M. laxa (1-14\%) (Figure 2a,b). Again the two isolates showed differences in sensitivity to fungicides. Rovral and Folicur solo showed the highest efficacy against $M$. laxa isolates.

\section{Half dosages of fungicides}

Fungicides (with active ingredients of copper and sulphur) applied at $0.5 \mathrm{x}$ dosage recommended by the manufacturer in organic production showed relatively high percent growth capacity of the brown rot fungus (31-83\%) (Figure $3 a, b$ ). Again the two isolates showed differences in sensitivity to fungicides. Again sulphur had very low in vitro
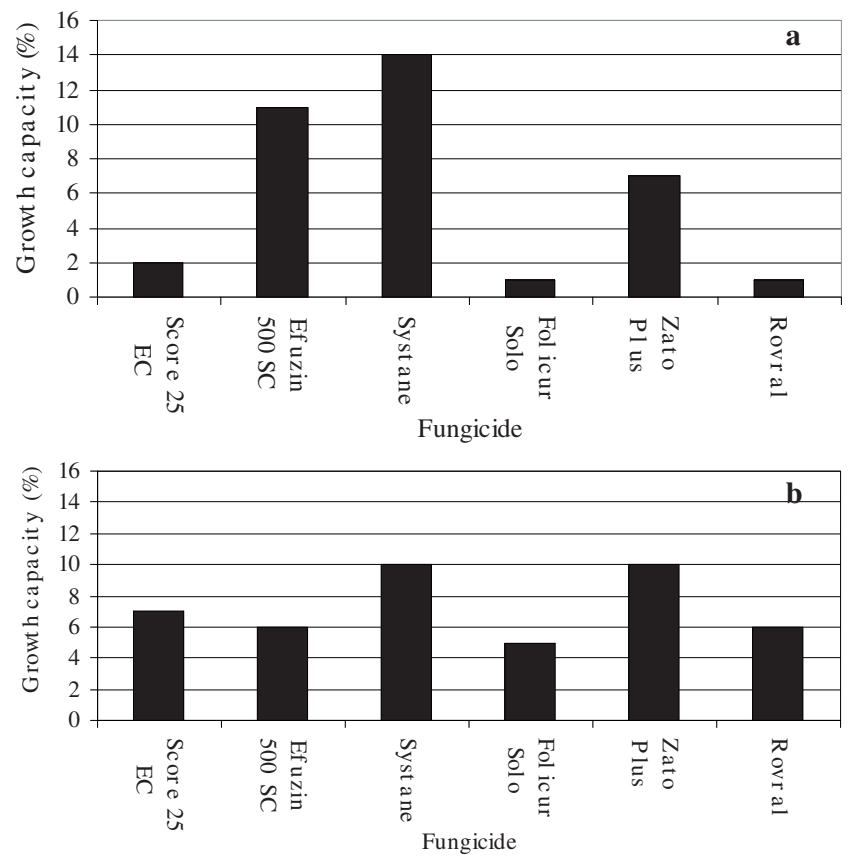

Figure 2. Percent growth capacity of two Monilinia laxa isolates (a and b) for 6 fungicides (approved in integrated production) admended on PDA plates at $1 \mathrm{x}$ dosage recommended by the manufacturer.
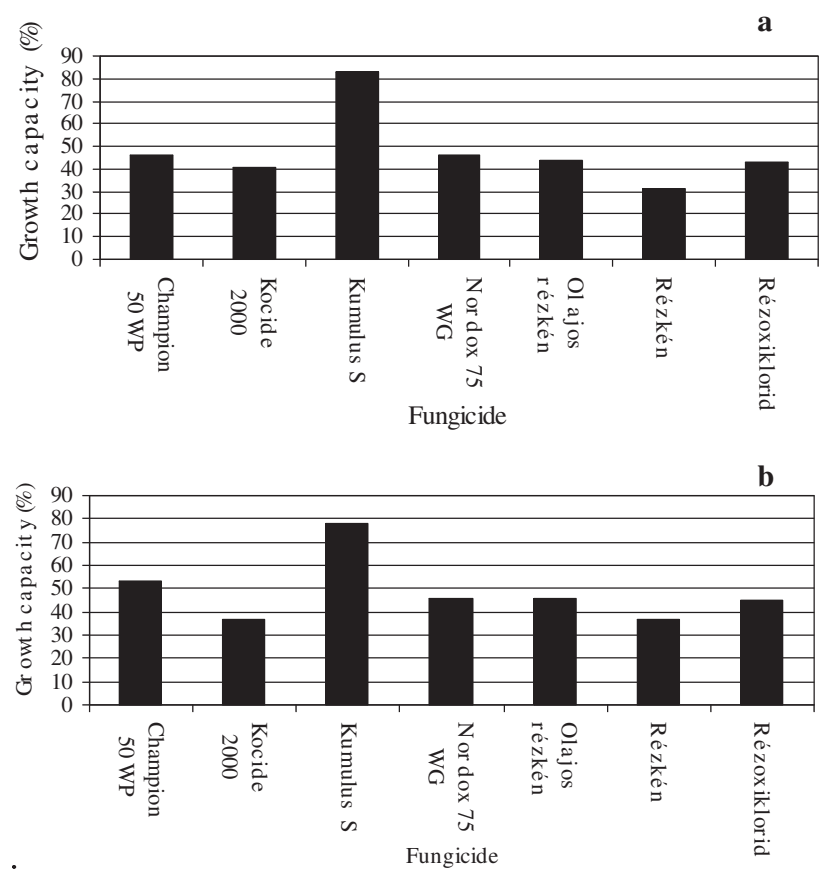

Figure 3. Percent growth capacity of two Monilinia laxa isolates (a and b) for 7 fungicides (organically approved) admended on PDA plates at $0.5 \mathrm{x}$ dosage recommended by the manufacturer .

effeciacy against brown rot. Again, Rézkén showed the highest and Kumilus $\mathrm{S}$ the lowest efficacy against brown rot.

Fungicides applied at $0.5 \mathrm{x}$ dosage recommended by the manufacturer in integrated production showed relatively low percent growth capacity of the brown rot fungus (3-27\%) (Figure 4a,b). Again the two isolates showed differences in sensitivity to fungicides. Again, Rovral and Folicur solo showed the highest efficacy against brown rot. 

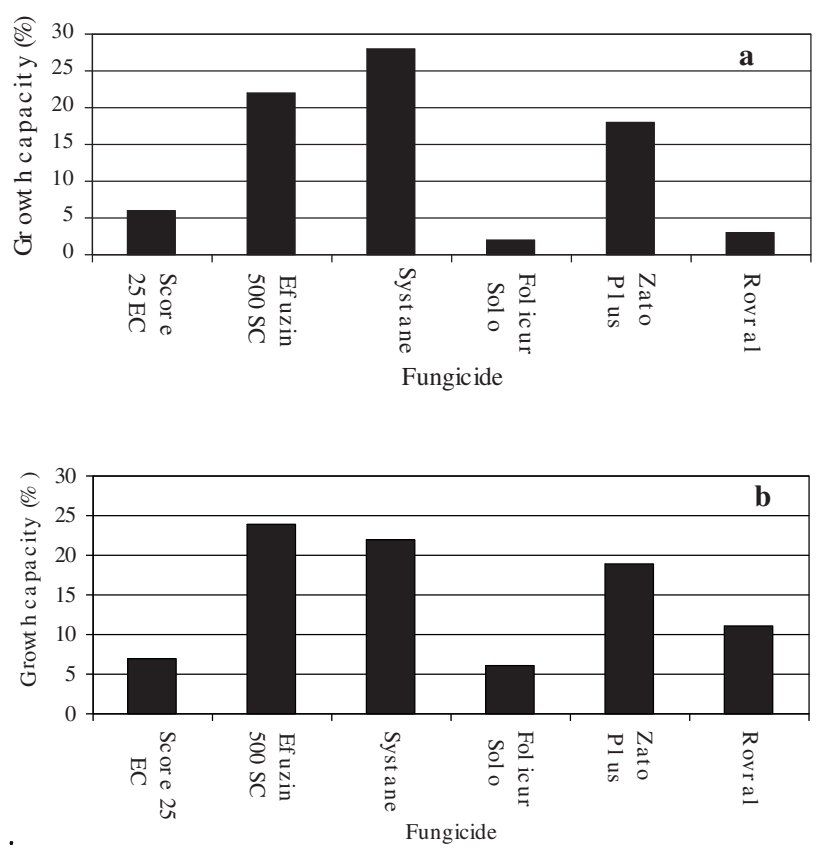

Figure 4. Percent growth capacity of two Monilinia laxa isolates (a and b) for 6 fungicides (approved in integrated production) admended on PDA plates at $0.5 \mathrm{x}$ dosage recommended by the manufacturer.

\section{Acknowledgements}

The study was supported by the NKTH programme (OM00227/2008) and by the research programme of OTKA (K 78399) as well as by a János Bolyai Research Fellowship.

\section{References}

Anonymous (2000): IFOAM Basic Standards for Organic Production and Processing, Tholey-Theley Press, New York, USA.

Batra, L. R. (1991): World species of Monilinia (Fungi): Their ecology, biosystematics and control. Mycologia Memoir, No. 16. J. Cramer, Berlin, Germany.

Byrde, R. J. W. \& Willetts, H. J. (1977): The Brown Rot Fungi of Fruit. Their Biology and Control. Pergamon Press, Oxford.

Cross J.V. \& Dickler E. (1994): Guidelines for integrated production of pome fruits in Europe. Technical guideline III, IOBC/WPRS Bulletin 17 (9): 1-8.

Holb, I. J. (2003): The brown rot fungi of fruit crops (Monilinia spp.). I. Important features of their biology. Int. J. Hortic. Sci. 9 (3-4): 23-36.

Holb, I. J. (2004): The brown rot fungi of fruit crops (Monilinia spp.). III. Important features of their disease control. Int. J. Hortic. Sci. 10 (4): 31-48.

Holb, I. J. \& Schnabel, G. (2005): Effect of fungicide treatments and sanitation practices on brown rot blossom blight incidence, phytotoxicity, and yield for organic sour cherry production. Plant Dis. 89:1164-1170.

Soltész, M. (1997): Resistance to pest and diseases. Pages 71-84 [in: Integrated Fruit Production. M. Soltész, ed.] Mezőgazda Kiadó, Budapest, Hungary. (In Hungarian)

Tamm, L., Minder, C. E. \& Flückinger, W. (1995): Phenological analyses of brown rot blossom blight of sweet cherry caused by Monilinia laxa. Phytopathology 85: 401-408.

Wormald, H. (1954): The brown rot disease of fruit trees. Ministry of Agriculture, Fisheries and Food, Tech. Bull. No. 3, Interscience Publishers, London. 